УДК 796.8+796.082.1+796.05

doi: $10.15330 /$ fcult.36.58-65

Олег Скирта, Наталія Гуцул,

Володимир Рихаль, Ігор Вовк

\title{
ПОРІВНЯЛЬНИЙ АНАЛІЗ РІВНЯ ТЕХНІКО-ТАКТИЧНОЇ ПІДГОТОВЛЕНОСТІ КІКБОКСЕРІВ-АМАТОРІВ ТА КІКБОКСЕРІВ- ПРОФЕСІОНАЛІВ В РОЗДІЛІ К-1
}

\begin{abstract}
Мета. Провести порівняння рівня техніко-тактичної підготовленості кваліфікованих кікбоксерів-аматорів та кікбоксерів-професіоналів в розділі К-1. Методи. У педагогічному дослідженні прийняли участь 40 кікбоксерів, умовно розділених на дві групи: 22 спортсмена-аматори високої кваліфікаціі, $i$ 18 спортсменів-професіоналів. Тестування техніко-тактичної підготовленості кікбоксерів (ISKA) y розділі K-1 за вдосконаленою методикою В.А. Еганова, дозволяє широко, об 'єктивно і швидко діагностувати рівень сформованої техніко-тактичної підготовленості. Результати. Дослідження дозволило виявити істотні відмінності в рівні техніко-тактичної підготовленості кікбоксерів, щзо увійшли до групи спортсменів-професіоналів і кікбоксерів-аматорів високої кваліфікації в розділі К-1. В змагальній діяльності рівень активності в атаці, контратаці у відповідь і контратаці на зустріч у двобою, по відношенню до суперника, в групі спортсмени професіонали мали вищий рівень відповідних показників ніж у кікбоксерів аматорів. Активність у зустрічній контратаці за допомогою ударів руками, ногами $i$ колінами у спортсменів-аматорів є нижче середнього рівня, а у професіоналів, означений показник значно вищий. Професіонали переважають аматорів у показнику надійності захисту при чому рівень захисних дій від ударів ногами в обох групах нижчий ніж від ударів руками і колінами. Висновок. Встановлено, щьо кікбоксери у розділі K-1 активніше використовують у нападі удари руками, ніж ногами $i$ колінами. 3 переходом на професійний ринг, у спортсменів підвищуються наступні показники: рівень активності та надійності ударів ногами і колінами. 3 переходом на професійний ринг, підвищується рівень спортивної кваліфікації, кікбоксери-професіонали покращують показники надійності захисних дій в верхній (голову) в середній (тулуб) рівні, але захисні дії від ударів в нижній рівень продовжують знаходитись не на належному рівні. У кікбоксерів в розділі $K-1$, з переходом на професійний ринг спостерігається значне підвищення загального рівня техніко-тактичної підготовленості.
\end{abstract}

Ключові слова: техніко-тактична підготовка, кікбоксинг, аматори, професіонали.

The aim of the study. To compare the level of technical and tactical training of qualified amateur kickboxers and professional kickboxers in section $\mathrm{K}-1$. Methods. The pedagogical study involved 40 kickboxers, divided into two groups: 22 highly qualified amateur athletes, and 18 professional athletes. Testing of technical and tactical training of kickboxers (ISKA) in section $K-1$ according to the improved method of Eganov, allows you to widely, objectively and quickly diagnose the level of technical and tactical preparedness. Results. The study revealed significant differences in the level of technical and tactical training of kickboxers who were included in the group of professional athletes and amateur kickboxers of high qualification in section K-1. In competitive activities, the level of activity in attack, counterattack in response and counterattack to meet in a duel, in relation to the opponent, in the group of professional athletes had a higher level of performance than amateur kickboxers. Activity in the counterattack with the help of punches, kicks and knees in amateur athletes is below average, and in professionals, this figure is much higher. Professionals outnumber amateurs in terms of protection reliability, and the level of protective action against kicks in both groups is lower than from kicks and knees. Conclusions. It has been established that kickboxers in the $K-1$ section use punches more actively in the attack than kicks and knees. With the transition to the professional ring, athletes increase the following indicators: the level of activity and reliability of kicks and knees. With the transition to the professional ring, the level of sports skills increases, professional kickboxers improve the reliability of protective actions in the upper (head) in the middle (torso) level, but protective actions against blows to the lower level continue to be at the wrong level. $K-1$, with the transition to the professional ring there is a significant increase in the overall level of technical and tactical training.

Keywords: technical and tactical preparedness, kickboxing, amateurs, professionals,

Постановка проблеми та аналіз результатів останніх досліджень. К-1 - є одним із рингових розділів кікбоксінгу "ІСКА” [10], в якому правилами змагань дозволяється використовувати удари руками, ногами і коліньми. При чому, користуватись ударом коліном дозволено як з дистанції, так і в клінчі. За думкою деяких фахівців, да-

(C) Скирта О., Гуцул Н., Рихаль В.,

Вовк I., 2020 
ний розділ має найбільші перспективи розвитку як у аматорському, так і в професійному кікбоксингу $[9,10]$.

Метою видатних кікбоксерів-аматорів Всесвітньої кікбоксерської спортивної асоціації ISKA $є$ виступи на таких турнірах 3 кікбоксингу як "K-1 World MAX", "GLORY”, "Bellator Kickboxing” та інших. Означені грандіозні події у світі єдиноборств проходять з санкції Всесвітньої кікбоксерської спортивної асоціації ISKA [10].

Контроль змагальної діяльності в єдиноборствах дозволяє виявляти сильні і слабкі сторони підготовленості спортсменів, з метою усунення недоліків і подальшого вдосконалення провідних якостей $[8,12-14]$.

На думку В.А. Еганова [5], одним з розділів, що сприяє підвищенню ефективності підготовки кікбоксерів до змагань, є методика оцінки рівня сформованості показників техніко-тактичної підготовленості. Складність такої оцінки полягає в тому, що змагальний бій являє собою структуру якісних переходів по вузловим ситуаціям двобою за допомогою атакуючих і захисних техніко-тактичних дій.

Порівняльний аналіз рівня техніко-тактичної підготовленості високо-кваліфікованих кікбоксерів аматорів і кікбоксерів професіоналів, на нашу думку, дозволить дослідити відмінності професійної “школи” кікбоксингу від аматорської і також дозволить визначити шляхи за якими спортсмени-аматори з мінімальними втратами зможуть адаптувати свою манеру ведення поєдинку до вимог професійного кікбоксингу.

У науково-методичній літературі публікації, що розкривають питання, які присвячені визначенню рівня техніко-тактичних підготовленості кікбоксерів аматорів і професіоналів (в нападі і в захисті), в розділі К-1 відсутні, що, на наш погляд, є однією 3 причин зниження спортивної майстерності кваліфікованих кікбоксерів-аматорів та заважає останнім здійснити перехід у професійний спорт з мінімальними втратами. Тому розгляд питання експрес-аналізу рівня техніко-тактичної підготовленості кікбоксерів аматорів і професіоналів у розділі К-1, з подальшим їх порівнянням ми вважаємо актуальним і необхідним.

У теорії та практиці спортивних єдиноборств застосовуються численні методи визначення рівня техніко-тактичної підготовленості. Одні з них більше, інші менш точні, і кожен з них вирішує одну й ту ж задачу. Варто виокремити наступні методи: кіно-відеозйомка $[4,7,11]$, біомеханічний аналіз $[6,2]$, тестування, анкетне опитування, яке за об'єктивністю, широтою і швидкістю діагностування, перевершує всі інші форми педагогічного контролю [3, 5].

Технологія педагогічного тестування за А.В. Егановим [5], полягає у визначенні чисельних значень показників техніко-тактичних дій (ударів) руками і ногами і захистів від них. Для цього кожен випробовуваний повинен оцінити себе суб'єктивно, грунтуючись на свій вже набутий раніше досвід за десятибальною шкалою виразності кожної із запропонованих характеристик техніко-тактичних дій по відношенню до супротивника. Відповіді на питання припускають виявлення кількісних характеристик техніко-тактичної підготовленості різної кваліфікації (надійність захисту від ударів руками, обсяг програної техніки ногами тощо). Заповнивши анкету в стаціонарних умовах, спортсмен може отримати інформацію про параметри техніко-тактичної підготовленості вже через 8-10 хвилин.

Перевага даної методики тестування полягає у можливості отримання оперативної інформації про індивідуальні характеристики ударних дій в нападі і захисних дій від ударів руками і ногами суперників. Але даний тест був розроблений автором 3 метою визначення рівня сформованої техніко-тактичної підготовленості в захисних діях кікбоксерів. Також автором не враховувались техніко-тактичні дії коліньми в нападі, та захисні дії від означених ударів, що властиві розділу К-1, і в питаннях, щодо контрата- 
куючих дій кікбоксерів розмежовувались поняття контратаки у відповідь та контратаки на зустріч.

Узагальнюючи вище викладену інформацію, можна зробити висновок, що методичне обгрунтування рингового розділу К-1 кікбоксінгу "ICКА” знаходиться не на належному рівні, і питання експрес-аналізу (педагогічного тестування) рівня технікотактичної підготовленості кікбоксерів потребує більш детального розгляду.

Мета дослідження - провести порівняння рівня техніко-тактичної підготовленості кваліфікованих кікбоксерів-аматорів та кікбоксерів-професіоналів в розділі К-1.

Методи дослідження. Відповідно до теми дослідження нами було проведено аналіз і узагальнення науково-методичної літератури. Емпіричний рівень досліджень: педагогічне спостереження; педагогічне тестування; методи математичної статистики. Педагогічне тестування здійснювалося з метою визначення рівня техніко-тактичної підготовленості кікбоксерів "ІСКА” у розділі К-1 на Чемпіонаті України 2019 р. в м. Києві, на Чемпіонаті Світу з кікбоксингу ISKA 2019 р. в м. Корк (Ірландія), на Відкритому чемпіонаті світу з кікбоксингу ISKA з аматорського К-1 2019 р. в м. Мілан (Італія), на професійному турнірі з кікбоксингу "SIAM WARRIORS" 2019 р. в м. Корк (Ірландія), на міжнародному турнірі $з$ професійного кікбоксингу “КОК” 2019 р. в м. ЛіптовськийМікулаш (Словаччина). В тестуванні приймали участь 40 кікбоксерів, розділених на дві групи: кваліфіковані спортсмени-аматори (МС і МСУМК України) в кількості 22 чоловік, та кікбоксери-професіонали, у кількості 18 чоловік. Спортсменам пропонувалось заповнити тест, перед початком якого вони повинні були ознайомитись з інструкцією, а потім переходити до самооцінки сформованої техніко-тактичної підготовленості шляхом закреслення цифри на десятибальній шкалі, яка відповідає в більшій мірі думці і рівню їх підготовленості. Тест містив 43 питання, умовно розділені на 17 блоків, 3 різною кількістю питань в кожному (13 блоків містили по 3 питання, 4 блоки - по одному питанню), що дозволяють визначити відповідні показники виконання ударних технікотактичних дій руками, ногами і коліньми, та захисних дій від означених ударів.

Обробка результатів тестування проводилася за допомогою методів математичної статистики з розрахунком визначення вірогідності розходжень $(\mathrm{p} \leq 0,05)$ за МаннаУітні. За допомогою пакета Statistika 7,0 розраховувалося середнє арифметичне значення (M) і стандартна похибка (m) показників техніко-тактичної підготовленості.

Результати дискусія. Дослідження дозволило виявити істотні відмінності в рівні техніко-тактичної підготовленості (ТТП) кікбоксерів, що увійшли до групи спортсменів-професіоналів (СП) і кікбоксерів, з яких була сформована група спортсменів-аматорів високої кваліфікації (СА) в розділі К-1. Результати дослідження викладені в табл. 1.

Так, оцінюючи рівень активності в атаці, контратаці у відповідь і контратаці на зустріч у двобою, по відношенню до суперника, в групі СП був значно вищий рівень $(\mathrm{P}<0,05)$ відповідних показників ніж у кікбоксерів CA, при чому, активність в атаці за допомогою ударних техніко-тактичних дій (ТТД) руками кікбоксерів CA $(5,0 \pm 0,7)$ перевищує відповідну активність ногами $(4,3 \pm 1,4)$ і колінами $(4,5 \pm 1,4)$. Кікбоксери групи СП майже однаково оцінили активні дії ногами $(5,9 \pm 2,7)$ і колінами $(5,6 \pm 2,6)$, визначивши пріоритет в атакуючих ударних діях руками $(6,3 \pm 1,4)$. Активність у контратаці у відповідь кікбоксерів СА и СП за допомогою ніг і колін, знаходяться майже в однаковому діапазоні оцінки (СА: ноги $-4,0 \pm 1,1$, коліна $-3,9 \pm 0,8$; КС: ноги $5,6 \pm 1,5$, коліна $-5,5 \pm 1,9)$. В обох групах було досліджено більший рівень активності в контратаці у відповідь дії за допомогою ударів руками (CA $-4,3 \pm 0,5 ; \mathrm{KC}-6,1 \pm 2,0)$.

Активність у зустрічній контратаці за допомогою ударів руками, ногами і ко-

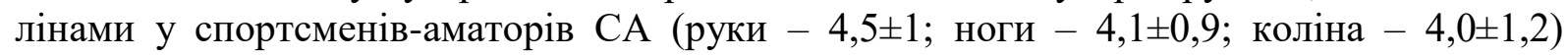


оцінена нижче середнього рівня, а у професіоналів ПС (руки - 6, $1 \pm 1,9$; ноги $-5,9 \pm 2,0$; коліна $-6,0 \pm 1,4)$, означений показник значно вищий і знаходиться майже в однаковому діапазоні. Таким чином, тестування дозволило виявити більшу активність ударних дій в нападі за допомогою рук, ніж за допомогою ніг і колін.

Під надійністю атакуючих і контратакуючих дій, в тесті спортсменами оцінювалась кількість і якість ударів, які відзначаються боковими суддями у двобої як результативні (не припинені захистом), по відношенню до супротивника. За результатами дослідження було виявлено, що надійність атаки за допомогою ударів руками в обох групах (CA - 4,5 $\pm 0,8 ;$ ПС $-6,4 \pm 1,3)$ перевищує означений показник надійності технікотактичних дій за допомогою ніг (CA $-4,3 \pm 1,9$; ПС $-5,9 \pm 2,1)$, і за допомогою колін $(\mathrm{CA}-3,6 \pm 1,2 ; \Pi \mathrm{C}-5,5 \pm 2,5)$.

Показник надійності контратакуючих у відповідь ударів руками $(4,8 \pm 0,7)$ спортсменами-аматорами оцінювався більш високо, ніж відповідні показники ТТД ногами $(4,0 \pm 1,2)$ і колінами $(3,4 \pm 1,2)$. Кікбоксери-професіонали надійніше виконують контратаки у відповідь руками $(5,9 \pm 1,5)$ і ногами $(5,8 \pm 1,8)$, ніж колінами $(5,3 \pm 2)$.

Надійність зустрічних контратакуючих ТТД кікбоксерів СА має більш високі показники в ударних діях руками $(4,9 \pm 0,6)$, ніж ногами $(4,5 \pm 1,5)$ і коліньми $(4,5 \pm 1,5)$. У кікбоксерів-професіоналів було виявлено перевагу в контратаках на зустріч ударами ногами $(6,3 \pm 0,7)$ ніж ударами руками $(5,7 \pm 1,6)$ і колінами $(5,3 \pm 2,2)$, що опосередковано вказує на те, що зі зростанням майстерності і переходом на професійний ринг, кікбоксери починають надійніше використовувати зустрічні удари ногами.

Таблиия 1 Результати тестування рівня техніко-тактичної підготовленості кікбоксерів в розділі К -1

\begin{tabular}{|c|c|c|c|c|c|}
\hline $\begin{array}{c}\mathrm{N} \\
1 \backslash 1\end{array}$ & $\begin{array}{c}\text { Показники рівня } \\
\text { техніко-тактичних } \\
\text { дій } \\
\end{array}$ & $\begin{array}{c}\text { Спосіб виконання } \\
\text { техніко-тактичних } \\
\text { дій }\end{array}$ & $\begin{array}{c}\text { Спортсмени- } \\
\text { аматори }(\mathrm{M} \pm \mathrm{m})\end{array}$ & $\begin{array}{l}\text { Спортсмени- } \\
\text { професіонали } \\
(\mathrm{M} \pm \mathrm{m})\end{array}$ & $\mathrm{P}$ \\
\hline \multirow[t]{3}{*}{1.} & \multirow{3}{*}{ Активність в атаці } & руками & $5.0 \pm 0.7$ & $6.3 \pm 1.4$ & $\mathrm{P}<0,05$ \\
\hline & & ногами & $4.3 \pm 1.4$ & $5.9 \pm 2.7$ & $\mathrm{P}<0,05$ \\
\hline & & коліньми & $4.5 \pm 1.4$ & $5.6 \pm 2.6$ & $\mathrm{P}<0,05$ \\
\hline \multirow[t]{3}{*}{2.} & \multirow{3}{*}{$\begin{array}{l}\text { Активність } \\
\text { у контратаці } \\
\text { у відповідь } \\
\end{array}$} & руками & $4.3 \pm 0.5$ & $6.1 \pm 2.0$ & $\mathrm{P}<0,05$ \\
\hline & & ногами & $4.0 \pm 1.1$ & $5.6 \pm 1.5$ & $\mathrm{P}<0,05$ \\
\hline & & коліньми & $3.9+0.8$ & $5.5 \pm 1.9$ & $\mathrm{P}<0,05$ \\
\hline \multirow[t]{3}{*}{3.} & \multirow{3}{*}{$\begin{array}{l}\text { Активність } \\
\text { у контратаці на } \\
\text { зустріч }\end{array}$} & руками & $4.5 \pm 1.0$ & $6.1 \pm 1.9$ & $\mathrm{P}<0,05$ \\
\hline & & ногами & $4.1 \pm 0.9$ & $5.9 \pm 2.0$ & $\mathrm{P}<0,05$ \\
\hline & & коліньми & $4.0 \pm 1.2$ & $6.0 \pm 1.4$ & $\mathrm{P}<0,05$ \\
\hline \multirow[t]{3}{*}{4.} & \multirow{3}{*}{ Надійність атаки } & руками & $4.5 \pm 0.8$ & $6.4 \pm 1.3$ & $\mathrm{P}<0,05$ \\
\hline & & ногами & $4.3 \pm 1.9$ & $5.9 \pm 3.1$ & $\mathrm{P}<0,05$ \\
\hline & & коліньми & $3.6 \pm 1.2$ & $5.5 \pm 2.5$ & $\mathrm{P}<0,05$ \\
\hline \multirow[t]{3}{*}{5.} & \multirow{3}{*}{$\begin{array}{l}\text { Надійність } \\
\text { у контратаці } \\
\text { у відповідь }\end{array}$} & руками & $4.8 \pm 0.7$ & $5.9 \pm 1.5$ & $\mathrm{P}<0,05$ \\
\hline & & ногами & $4.0 \pm 1.2$ & $5.8 \pm 1.8$ & $\mathrm{P}<0,05$ \\
\hline & & коліньми & $3.4 \pm 1.2$ & $5.3 \pm 2.0$ & $\mathrm{P}<0,05$ \\
\hline \multirow[t]{3}{*}{6.} & \multirow{3}{*}{$\begin{array}{l}\text { Надійність } \\
\text { у контратаці на } \\
\text { зустріч }\end{array}$} & руками & $4.9 \pm 0.6$ & $5.7 \pm 1.6$ & $\mathrm{P}<0,05$ \\
\hline & & ногами & $4.5 \pm 1.5$ & $6.3 \pm 0.7$ & $\mathrm{P}<0,05$ \\
\hline & & коліньми & $3.8 \pm 0.9$ & $5.3 \pm 2.2$ & $\mathrm{P}<0,05$ \\
\hline \multirow[t]{3}{*}{7.} & \multirow{3}{*}{$\begin{array}{l}\text { Об’єм оцінюваної } \\
\text { техніки }\end{array}$} & руками & $5.0 \pm 1.1$ & $6.2 \pm 1.7$ & $\mathrm{P}<0,05$ \\
\hline & & ногами & $4.5 \pm 1.1$ & $5.6 \pm 2.1$ & $\mathrm{P}<0,05$ \\
\hline & & коліньми & $3.9 \pm 1.6$ & $4.8 \pm 2.4$ & $\mathrm{P}<0,05$ \\
\hline
\end{tabular}


Продовж. табл. 1

\begin{tabular}{|c|c|c|c|c|c|}
\hline \multirow[t]{3}{*}{8.} & \multirow{3}{*}{$\begin{array}{l}\text { Рівень активності } \\
\text { супротивника в } \\
\text { нападі (атака, } \\
\text { контратаки у } \\
\text { відповідь і на } \\
\text { зустріч) }\end{array}$} & руками & $5.6 \pm 1.5$ & $5.7 \pm 1.5$ & $\mathrm{P}>0,05$ \\
\hline & & ногами & $4.8 \pm 1.7$ & $4.3 \pm 1.4$ & $\mathrm{P}>0,05$ \\
\hline & & коліньми & $5.2 \pm 1.6$ & $4.7 \pm 1.8$ & $\mathrm{P}>0,05$ \\
\hline \multirow[t]{3}{*}{9.} & \multirow{3}{*}{$\begin{array}{l}\text { Надійність } \\
\text { захисту }\end{array}$} & від ударів руками & $4.8 \pm 0.9$ & $6.4 \pm 1.9$ & $\mathrm{P}<0,05$ \\
\hline & & від ударів ногами & $4.5 \pm 1.0$ & $6.1 \pm 0.9$ & $\mathrm{P}<0,05$ \\
\hline & & від ударів коліньми & $4.6 \pm 0.8$ & $6.3 \pm 1.2$ & $\mathrm{P}<0,05$ \\
\hline \multirow[t]{3}{*}{10.} & \multirow{3}{*}{$\begin{array}{l}\text { Об’єм програної } \\
\text { техніки }\end{array}$} & від ударів руками & $4.8 \pm 1.7$ & $4.3 \pm 2.0$ & $\mathrm{P}>0,05$ \\
\hline & & від ударів ногами & $4.9 \pm 1.8$ & $4.9 \pm 1.3$ & $\mathrm{P}>0,05$ \\
\hline & & від ударів коліньми & $4.6 \pm 1.2$ & $4.1 \pm 1.5$ & $\mathrm{P}>0,05$ \\
\hline \multirow[t]{3}{*}{11.} & \multirow{3}{*}{$\begin{array}{l}\text { Вміння організації } \\
\text { захисту в цілому }\end{array}$} & від ударів руками & $4.3 \pm 0.8$ & $6.9 \pm 1.5$ & $\mathrm{P}<0,05$ \\
\hline & & від ударів ногами & $4.5 \pm 1.1$ & $6.9 \pm 1.7$ & $\mathrm{P}<0,05$ \\
\hline & & від ударів коліньми & $4.4 \pm 1.3$ & $5.8 \pm 1.9$ & $\mathrm{P}<0,05$ \\
\hline \multirow[t]{3}{*}{12.} & \multirow{3}{*}{$\begin{array}{l}\text { Вміння організації } \\
\text { захисту від ударів } \\
\text { в верхній рівень }\end{array}$} & від ударів руками & $4.5 \pm 1.1$ & $7.1 \pm 1.6$ & $\mathrm{P}<0,05$ \\
\hline & & від ударів ногами & $4.5 \pm 1.3$ & $7.0 \pm 0.7$ & $\mathrm{P}<0,05$ \\
\hline & & від ударів коліньми & $4.5 \pm 0.8$ & $5.7 \pm 1.9$ & $\mathrm{P}<0,05$ \\
\hline \multirow[t]{3}{*}{13.} & \multirow{3}{*}{$\begin{array}{l}\text { Вміння організації } \\
\text { захисту від ударів } \\
\text { в середній рівень }\end{array}$} & від ударів руками & $4.0 \pm 0.5$ & $6.8 \pm 1.4$ & $\mathrm{P}<0,05$ \\
\hline & & від ударів ногами & $4.5 \pm 1.3$ & $6.3 \pm 1.5$ & $\mathrm{P}<0,05$ \\
\hline & & від ударів коліньми & $4.4 \pm 0.7$ & $5.7 \pm 1.7$ & $\mathrm{P}<0,05$ \\
\hline 14. & $\begin{array}{l}\text { Вміння організації } \\
\text { захисту від ударів } \\
\text { в нижній рівень }\end{array}$ & від ударів ногами & $3.9 \pm 1.6$ & $5.9 \pm 0.9$ & $\mathrm{P}<0,05$ \\
\hline 15. & $\begin{array}{l}\text { Надійність } \\
\text { захисту від } \\
\text { підсікань } \\
\end{array}$ & ногами & $4.3 \pm 1.3$ & $5.6 \pm 2.1$ & $\mathrm{P}<0,05$ \\
\hline 16. & $\begin{array}{l}\text { Вміння виконува- } \\
\text { ти удари в комбі- } \\
\text { націях (рука-нога, } \\
\text { нога-рука, рука- } \\
\text { коліно і т.д.) }\end{array}$ & $\begin{array}{l}\text { руками, ногами, } \\
\text { коліньми }\end{array}$ & $5.1 \pm 1.7$ & $7.0 \pm 1.1$ & $\mathrm{P}<0,05$ \\
\hline 17. & $\begin{array}{l}\text { Загальній рівень } \\
\text { техніко-тактичної } \\
\text { підготовленості }\end{array}$ & $\begin{array}{l}\text { руками, ногами, } \\
\text { коліньми }\end{array}$ & $5.4 \pm 1.1$ & $6.8 \pm 1.1$ & $\mathrm{P}<0,05$ \\
\hline
\end{tabular}

Під об'ємом оцінюваної техніки, в тесті, кікбоксери повинні були визначить рівень використання різних ударів, які доходять до цілі і одержують оцінку бокових суддів, по відношенню до супротивників. Спортсмени СА і СП вважають, що показник об'єму оцінюваної техніки ударних дій руками (CA $-5,0 \pm 1,1$; СП $-6,2 \pm 1,7)$ перевершують відповідні показники ногами (CA $-4,5 \pm 1,1$; СП $-5,6 \pm 2,1)$ і колінами (CA $3,9 \pm 1,6 ; \mathrm{C} \Pi-4,8 \pm 2,4)$.

Оцінити рівень активності супротивника в нападі спортсменам пропонувалось шляхом визначення об’єму активних дій супротивника (в атаці, в контратаці у відповідь і контратаці на зустріч разом) відносно себе.

У кікбоксерів-аматорів і у спортсменів-професіоналів оцінка активності супро-

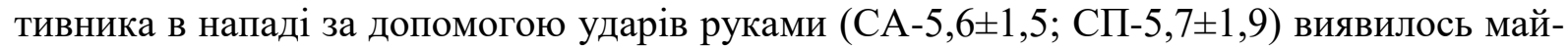
же однаковою.

Проте, рівень активності супротивника в нападі за допомогою ударів ногами $(4,8 \pm 1,7)$ і колінами $(5,2 \pm 1,6)$ кікбоксерами-аматорами оцінювався вище ніж спортсменами-професіоналами (за допомогою ніг - 4,3 $\pm 1,4$; за допомогою колін $-4,7 \pm 1,8$ ). 
Надійність захисту (захисних техніко-тактичних дій) визначалась як вміння контролювати атакуючи (контратакуючи) дії супротивника, вміння не програвати, очки. Спортсменами обох груп було визначено більший рівень надійності захисних дій від ударів руками $(\mathrm{CA}-4,8 \pm 0,9 ; \mathrm{C} \Pi-6,4 \pm 1,9)$ і ударів коліньми ( $\mathrm{CA}-4,6 \pm 0,8 ; \mathrm{C}$ $6,3 \pm 1,2)$ ніж від ударів ногами СА $-1,5 \pm 1,0$ та СП $-6,3 \pm 1,2$ відповідно. Таким чином, професіонали переважають аматорів у показнику надійності захисту при чому рівень захисних дій від ударів ногами в обох групах нижчий ніж від ударів руками і колінами.

Нами було встановлено, що показник надійності захисту від ударів в верхній рівень в групі СА оцінюється однаково від ударів рукам $(4,5 \pm 1,1)$,ногами $(4,5 \pm 1,3)$ і колінами $(4,5 \pm 0,8)$. У групі кікбоксерів-професіоналів показник вміння організації захисту від ударів в верхній рівень від ударів руками $(7,1 \pm 1,6)$ і ногами $(7,0 \pm 0,7)$ значно вищій ніж від ударів коліньми $(5,7 \pm 1,7)$

За результатами тестування спортсмени-професіонали значно краще використовують захисні дії від ударів руками, ногами і колінами в середній рівень (тулуб). В групі кікбоксерів СА було виявлено вищий рівень вміння організації захисту від ударів ногами $(4,5 \pm 1,3)$ і колінами $(4,4 \pm 0,7)$ ніж від ударів руками $(4,0 \pm 0,5)$ що за нашими спостереженнями свідчить про більш ефективну роботу руками в нападі ніж ногами і колінами у кікбоксерів означеної кваліфікації. В групі професіоналів навпаки, вміння організації захисту від ударів руками в тулуб $(6,8 \pm 1,4)$ вище ніж від ударів ногами $(6,3 \pm 1,5)$ та від ударів колінами $(5,7 \pm 1,7)$.

Згідно правил змагань, в розділі К-1 дозволено виконувати тільки кругові удари ногами (раунд-кік) вздовж стегна і гомілки (у аматорів - лише вздовж стегна), зовнішньої та внутрішньої сторін. В результаті тестування та було виявлено низький показник

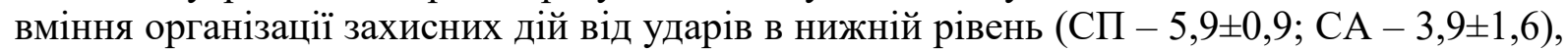
що свідчить, за нашими спостереженнями, про високу ефективність ударів в нижній рівень в розділі К-1 серед аматорів, і деяку зневажливість до означених видів ударів у професіоналів. Вище описане, на нашу думку пов'язано з приділенням значної уваги до набивки поверхонь даних частин тіла професіоналами і навмисне не використання захисту стегон і гомілок з метою застосування в момент удару власної зустрічної контратаки ударами рук у голову.

У зв'язку з тим, що, за нашими спостереженнями, в розділі К-1 ТТД в нападі підсікання використовується спортсменами-аматорами лише епізодично, то вміння організації захисту від підсікань у групі СА $(3,9 \pm 1,6)$ має низький рівень. В групі професіоналів означений показник оцінюється значно вище $(5,9 \pm 0,9)$, хоча в деяких професійних лігах (турнірах) данні ттд забороняються правилами змагань.

В змагальній діяльності одним із найважливіших показників техніко-тактичної підготовленості в нападі є вміння виконувати удари в комбінаціях, поєднуючи технічні дії руками, ногами і коліньми в різних сполученнях (рука-нога, нога-рука, рука-коліно, коліно-рука, нога-коліно, коліно-нога і т.д.). Згідно одержаних результатів тестування, кікбоксери СП $(7,0 \pm 1,1)$ поєднують удари в комбінації значно краще спортсменіваматорів $(5,1 \pm 1,7)$.

Аналіз результатів тестування надав можливість визначити загальний рівень техніко-тактичної підготовленості кікбоксерів в обох групах. Так, самооцінка означе-

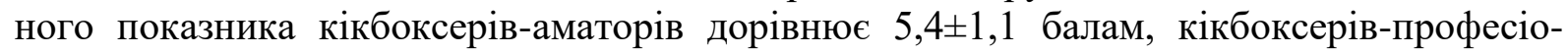
налів $-6,8 \pm 1,1$ балам. Узагальнюючи результати дослідження, ми прийшли до висновку, що з переходом кікбоксерів у професійний спорт, рівень їх техніко-тактичної підготовленості зростає.

\section{Висновки.}

1. В змагальній діяльності у кікбоксерів розділу К-1 відмічається більш висока активність у нападі (в атаці, контратаці у відповідь, контратаці на зустріч) за допо- 
могою техніко-тактичних дій руками, ніж за допомогою ударних дій ногами і колінами. 3 переходом на професійний ринг, рівень активності і надійності ударів ногами і колінами зростає, особливо в контратаках у відповідь і на зустріч.

2. 3 переходом на професійний ринг, підвищується рівень спортивної кваліфікації, кікбоксери-професіонали покращують показники надійності захисних дій в верхній (голову) та середній (тулуб) рівень, але, захисні дії від ударів в нижній рівень продовжують знаходитись на низькому рівні.

1. Атилов АА. Кик Боксинг Лоу-Кик. Ростов-на-Дону: Феникс, 2002. 560 с.

2. Васильев ОС, Сучилин ОС. Современные методики биомеханических измерений : компьютеризированный динамометрический комплекс. Теория и практика физической культуры. 2004; 3: 13-16

3. Галкин ПЮ, Галикиев СМ, Еганов ВА. Индивидуальная структура тактики защитных действий в четырёхраундовом бою боксёров высокой квалификации. Сб. науч. тр. кафедры теории и методики борьбы Урал. ГАФК. Челябинск, 2002; 5: 66-69.

4. Горбенко ВП, Горбенко ВП. Аналіз змагальної діяльності кікбоксерів (WPKA) у розділі орієнтал. Спортивна наука України. Науковий вісник Львівського державного університету фізичної культури. 2012; 5 (49): 32-38.

5. URL: http://www.sportscience.org.ua/index.php/Arhiv.html.

6. Сганов ВА. Методика обучения защитным технико-тактическим действиям в кикбоксинге [диссертация]. Челябинск; 2005. 171 с.

7. Осколков ВА, Агафонов АИ. Биомеханический анализ техники выполнения ударов ногами и руками в кикбоксинге. Ученые записки университета имени П.Ф. Лесгафта. 2010; 5(63): 64-67

8. Павлов СВ. Методика оценки технической и тактической подготовленности тхэквондистов в соревновательных поединках. Физическая культура: воспитание, образование, тренировка. 2003; 2 : $56-60$.

9. Платонов ВН. Система подготовки спортсменов в олимпийском спорте. Общая теория и её практические приложения: учеб. тренера высш. квалиф. Киев: Олимпийская литература, 2004. 808 с.

10. Саяпов РС, Змиенко РС. Вес тренерського слова - преимущество, которое всегда с тобой. Боевые искуства. 2007; 5: 45-47.

11. Федерація кікбоксингу України “ICKA”. URL: http://iska.com.ua/federation.

12. Яремко МО. Вдосконалення швидкісно-силових якостей в ударних прийомах кікбоксерів на етапі попередньої базової підготовки: дис. ... канд. наук з фіз. вих. і спорту. Львів, 2001. 226 с.

13. Evgen Prystupa, Andriy Okopnyy, Natalia Hutsul, Khrystyna Khimenes, Andriy Kotellnyk, Ihor Hryb, Maryan Pityn. Development of special physical qualities skilled kickboxers various style of competitive activity. Journal of Physical Education and Sport (JPES). 2019; 19 (2): 273-280. Doi:10.7752/jpes.

14. Pityn M., Okopnyy A., Tyravska O., Hutsul N., Ilnytsky I. Dynamic of indexes of technical and tactical actions of qualified kickboxer individual fighting style. Journal of Physical Education and Sport (JPES). 2017;17 (3): 1024-1030. Doi:10.7752/jpes.2017.s3157.

15. Zadorozhna, O., Okopnyy, A, Hutsul, N., Kotelnyk, A., Grashchenkova, Z., Perederiy, A., Pityn, M., \& Svistelnyk, I. Improving kickboxers' special physical preparedness which accounts for their individual tactical style and technical skills. Journal of Physical Education and Sport (JPES). 2019;19 (2): 1173-1179. URL: https://doi.org/10.7752/jpes.2019.02170.

\section{References}

1. Atilov AA. Kik Boksing Lou-Kik. Rostov-na-Donu: Feniks. 2002. $560 \mathrm{~s}$.

2. Vasilev OS. Suchilin OS. Sovremennye metodiki biomekhanicheskikh izmereniy : kompyuterizirovannyy dinamometricheskiy kompleks. Teoriya i praktika fizicheskoy kultury. 2004; 3: 13-16

3. Galkin PYu. Galikiyev SM. Eganov VA. Individualnaya struktura taktiki zashchitnykh deystviy v chetyrekhraundovom boyu bokserov vysokoy kvalifikatsii. Sb. nauch. tr. kafedry teorii i metodiki borby UralGAFK. Chelyabinsk; 2002;5:66-69.

4. Horbenko VP, Horbenko VP. Analiz zmahalnoi diialnosti kikbokseriv (WPKA) u rozdili oriiental. Sportyvna nauka Ukrainy. Naukovyi visnyk Lvivskoho derzhavnoho universytetu fizychnoi kultury. Elektronne naukove fakhove vydannia - chasopys: Lviv, LDUFK. 2012; 5(49): 32-38.

5. URL: http://www.sportscience.org.ua/index.php/Arhiv.html.

6. Gganov VA. Metodika obucheniya zashchitnym tekhniko-takticheskim deystviyam v kikboksinge [dissertatsiya]. Chelyabinsk, 2005. 171s.

7. Oskolkov VA. Agafonov AI. Biomekhanicheskiy analiz tekhniki vypolneniya udarov nogami i rukami v kikboksinge. Uchenye zapiski universiteta imeni P.F. Lesgafta. 2010;5(63):64-67. 
Скирта Олег, Гуиул Наталія, Рихаль Володимир, Вовк Ігор. Порівняльний аналіз рівня техніко-тактичної ...

8. Pavlov SV. Metodika otsenki tekhnicheskoy i takticheskoy podgotovlennosti tkhekvondistov v sorevnovatelnykh poedinkakh. Fizicheskaya kultura: vospitaniye. obrazovaniye. trenirovka. 2003; 2: 56-60.

9. Platonov VN. Sistema podgotovki sportsmenov v olimpiyskom sporte. Obshchaya teoriya i ee prakticheskiye prilozheniya: ucheb. trenera vyssh. kvalif. Kiyev: Olimpiyskaya literature, 2004. $808 \mathrm{~s}$.

10. Sayapov RS. Zmiyenko RS. Ves trenerskogo slova - preimushchestvo. kotoroe vsegda s toboy. Boevye iskustva. 2007; 5: 45-47.

11. 10 Federatsiia kikboksynhu Ukrainy "ISKA". URL: http://iska.com.ua/federation.

12. Iaremko MO. Vdoskonalennia shvydkisno-sylovykh yakostei v udarnykh pryiomakh kikbokseriv na etapi poperednoi bazovoi pidhotovky [dysertatsiia]. Lviv: Lviv derzh in-t fiz. Kultury, 2001. $226 \mathrm{~s}$.

13. Evgen Prystupa, Andriy Okopnyy, Natalia Hutsul, Khrystyna Khimenes, Andriy Kotellnyk, Ihor Hryb, Maryan Pityn. Development of special physical qualities skilled kickboxers various style of competitive activity. Journal of Physical Education and Sport (JPES). 2019; 19(2): 273-280. Doi: 10.7752/jpes.2019.s2041.

14. Pityn M., Okopnyy A., Tyravska O., Hutsul N., Ilnytsky I. Dynamic of indexes of technical and tactical actions of qualified kickboxer individual fighting style. Journal of Physical Education and Sport (JPES). 2017; 17(3): 1024-1030. Doi: 10.7752/jpes.2017.s3157.

15. Zadorozhna, O., Okopnyy, A, Hutsul, N., Kotelnyk, A., Grashchenkova, Z., Perederiy, A., Pityn, M., \& Svistelnyk, I. () Improving kickboxers' special physical preparedness which accounts for their individual tactical style and technical skills. Journal of Physical Education and Sport (JPES). 2019; 19(2): 1173-1179. URL: https://doi.org/10.7752/jpes.2019.02170.

\section{Цитування на цю статтю:}

Скирта О, Гуцул Н3, Рихаль ВІ, Вовк ІВ. Порівняльний аналіз рівня техніко-тактичної підготовленості кікбоксерів-аматорів та кікбоксерів-професіоналів в розділі К-1. Вісник Прикарпатського університету. Серія: Фізична культура. 2020 Листоп 24; 36: 58-65

\begin{tabular}{|c|c|}
\hline Відомості про автора: & Information about the author: \\
\hline $\begin{array}{l}\text { Скирта Олег - кандидат наук } 3 \text { фізичного вихо- } \\
\text { вання та спорту, старший викладач, Кременчу- } \\
\text { цький національний університет імені Михайла } \\
\text { Остроградського (Кременчук, Україна) }\end{array}$ & $\begin{array}{l}\text { Skyrta Oleh - Candidate of Sciences in Physical } \\
\text { Education and Sports, Senior Lecturer, Kremenchuk } \\
\text { Mykhailo Ostrohradskyi National University (Kre- } \\
\text { menchuk, Ukraine) }\end{array}$ \\
\hline \multicolumn{2}{|l|}{$\begin{array}{l}\text { e-mail: skgermes@i.ua } \\
\text { https://orcid.org/0000-0002-6881-2983 }\end{array}$} \\
\hline $\begin{array}{l}\text { Гуцул Наталія - кандидат наук з фізичного ви- } \\
\text { ховання та спорту, старший викладач, Українська } \\
\text { академія друкарств (Львів, Україна) }\end{array}$ & $\begin{array}{l}\text { Hutsul Natalia - Candidate of Sciences in Physical } \\
\text { Education and Sports, Senior Lecturer, Ukrainian } \\
\text { Academy of Printing (Lviv, Ukraine) }\end{array}$ \\
\hline \multicolumn{2}{|l|}{$\begin{array}{l}\text { e-mail: umbanathalie88@gmail.com } \\
\text { https://orcid.org/0000-0002-6080-2369 }\end{array}$} \\
\hline $\begin{array}{l}\text { Рихаль Володимир - аспірант, викладач, Львів- } \\
\text { ський державний університет фізичної культури } \\
\text { імені Івана Боберського (Львів, Україна) }\end{array}$ & $\begin{array}{l}\text { Rykhal Volodymyr - graduate student, teacher, Lviv } \\
\text { State University Physical Culture (Lviv, Ukraine ) }\end{array}$ \\
\hline \multicolumn{2}{|l|}{$\begin{array}{l}\text { e-mail: rykha18888@ gmail.com } \\
\text { https://orcid.org/0000-0002-1670-0066 }\end{array}$} \\
\hline $\begin{array}{l}\text { Вовк Ігор - завідувач кафедри фізичного вихо- } \\
\text { вання, викладач, Львівський національний аграр- } \\
\text { ний університет (Львів, Україна) }\end{array}$ & $\begin{array}{l}\text { Vovk Igor - Head of the Department of Physical } \\
\text { Education, teacher, Lviv National Agrarian University } \\
\text { (Lviv, Ukraine) }\end{array}$ \\
\hline & \\
\hline
\end{tabular}

